\title{
CANCER IN HUMAN IMMUNODEFICIENCY VIRUS PATIENTS- A STUDY FROM A REGIONAL CANCER CENTRE
}

\author{
Aparna Suryadevara ${ }^{1}$, Sanjeeva Kumari Chinta², Lakshmi Narsamma Putcha ${ }^{3}$ \\ ${ }_{1}^{1}$ Consultant, Department of Radiation Oncology, Basavatarakam Indo-American Hospital and Research Institute, Hyderabad, T. S. \\ 2Professor and HOD, Department of Radiation Oncology, MNJIO/Regional Cancer Centre, Hyderabad, T. S. \\ 3Blood Bank Medical Officer, MNJIO/Regional Cancer Centre, Hyderabad, T. S.
}

\section{BACKGROUND}

\section{ABSTRACT}

Patients with Human Immunodeficiency Virus (HIV) are at higher risk for cancers, either Acquired Immunodeficiency Syndrome (AIDS) defining cancers (ADCs) or non-AIDS defining cancers (NADCs). The pattern of HIV and malignancy is different among the Indian population and the literature on this topic is sparse.

The aim of this study is to evaluate the pattern and spectrum of malignancies in HIV positive patients at our institute.

\section{MATERIALS AND METHODS}

This is a Descriptive Study. A total of 15,964 patients were screened and of these 240 were positive for HIV (1.5\%). These patients were reviewed for demographics and type of malignancy.

\section{RESULTS}

The median age was 40 years for both males and females. Majority were females (61\%). Most common malignancy in males was head and neck cancer (HNNC) followed by non-Hodgkin's lymphoma (NHL), carcinoma penis, rectum and anal cancers. In females, most common malignancy was carcinoma cervix followed by carcinoma breast and HNNC, NHL and thyroid cancer. Overall, most common malignancies in HIV positive were carcinoma cervix (39\%), HNNC (16\%), carcinoma breast (7.4\%), carcinoma penis (6\%) and anal canal and rectum cancer (6\%).

\section{CONCLUSION}

Females who are HIV positive are more prone for malignancy, especially carcinoma cervix and breast. The incidence of carcinoma penis is high in HIV infected Indian males. Overall, the most common malignancies are carcinoma cervix and HNNC. The spectrum of malignancies and epidemiology in HIV positive patients from our institute is different from the western population, but comparable to other institutes within India.

\section{KEYWORDS}

Cancer, Human Immunodeficiency Virus, India.

HOW TO CITE THIS ARTICLE: Suryadevara A, Chinta SK, Putcha LN. Cancer in human immunodeficiency virus patientsa study from a regional cancer centre. J. Evolution Med. Dent. Sci. 2017;6(90):6309-6311, DOI: 10.14260/jemds/2017/1372

\section{BACKGROUND}

Patients with Human Immunodeficiency Virus (HIV) are at higher risk for cancers either Acquired Immunodeficiency Syndrome (AIDS) defining cancers (ADCs) or non-AIDS defining cancers (NADCs). ${ }^{1-4}$ The literature on Indian HIV patients and malignancy is sparse. 5 The ADCs include Kaposi's sarcoma, invasive cervical carcinoma and nonHodgkin's Lymphoma. The NADCs common in HIV include sites like anal canal, skin, liver, lung, mouth, throat, testes and Hodgkin's lymphoma according to western data. ${ }^{3}$ The pattern of HIV and malignancy is different among the Indians. ${ }^{4}$ So the aim of this study is to evaluate the pattern and spectrum of malignancies among HIV patients at our institute.

'Financial or Other Competing Interest': None.

Submission 08-09-2017, Peer Review 08-11-2017,

Acceptance 14-11-2017, Published 20-11-2017.

Corresponding Author:

Aparna Suryadevara,

8-3-404/2,

Yellareddyguda,

Ameerpet,

Hyderabad-500073,

Telangana, India.

E-mail: surya_aparna@yahoo.com

DOI: $10.14260 /$ jemds $/ 2017 / 1372$

\section{MATERIALS AND METHODS}

This is a Descriptive Study. Ethics committee approval is not routinely taken for retrospective studies at our institute. All diagnosed cases of malignancy at our institute undergo screening for HIV before starting treatment. All the patients with diagnosis of malignancy who were screened for HIV were included in the study from January 2009 to December 2012. A total of 15,964 patients were screened for HIV during this period. Among these all the HIV positive patients were reviewed in detail for demographics like age, sex and histological type of malignancy diagnosed. Patients with incomplete data were excluded from the study and a total of 189 patients were analysed.

\section{RESULTS}

Among the study population of 15,964 patients, $1.5 \%$ were positive for HIV $(240 / 15,964)$. The median age at presentation of malignancy in HIV positive patients in our study was 40 years for both male and female patients. There were more female HIV positive patients with cancer than men (61\% versus 39\%). Among the female HIV positive patients, the most common cancer was carcinoma cervix (64\%) followed by breast cancer (12\%) and anal/ rectal cancer (10\%). In HIV positive men with cancer, the most common site was head and neck cancer (36\%) (HNNC) followed by Non-Hodgkin's Lymphoma (NHL) (16\%), penile cancer 
(15\%) and anal/ rectal cancer (13\%). These results are summarised in Graph 1 and Table 1.

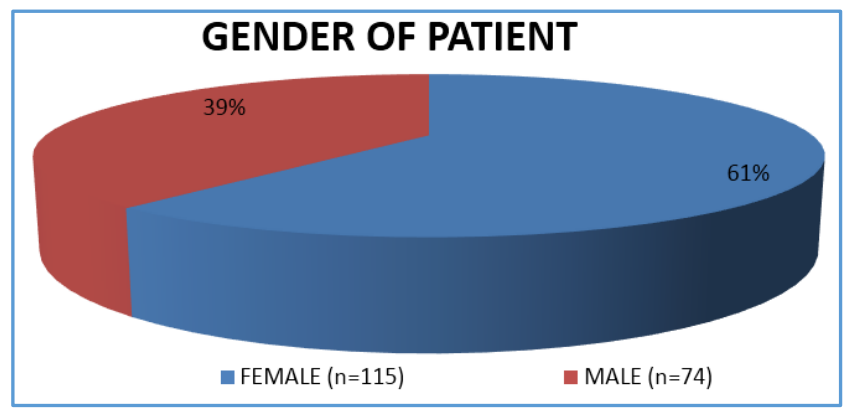

Graph 1. Showing the Gender of Patients with Malignancy and Human Immunodeficiency Virus Infection

\begin{tabular}{|c|c|c|c|}
\hline $\begin{array}{c}\text { Type of } \\
\text { Malignancy }\end{array}$ & $\begin{array}{l}\text { Male } \\
\text { n (\%) }\end{array}$ & $\begin{array}{c}\text { Female } \\
\text { n (\%) }\end{array}$ & $\begin{array}{c}\text { Overall n } \\
\text { (\%) }\end{array}$ \\
\hline $\begin{array}{c}\text { Cervix } \\
\text { carcinoma }\end{array}$ & $\mathrm{N} / \mathrm{A}$ & $74(64.34 \%)$ & $74(39.15 \%)$ \\
\hline HNNC & $27(36.48 \%)$ & $4(3.47 \%)$ & $30(15.87 \%)$ \\
\hline $\begin{array}{c}\text { Breast } \\
\text { carcinoma }\end{array}$ & 0 & $14(12.17 \%)$ & $14(7.4 \%)$ \\
\hline Penile cancer & $11(14.86 \%)$ & $\mathrm{N} / \mathrm{A}$ & $11(5.82 \%)$ \\
\hline $\begin{array}{l}\text { Anal canal } \\
\text { carcinoma }\end{array}$ & $4(5.4 \%)$ & $7(6.08 \%)$ & $11(5.82 \%)$ \\
\hline Rectal cancer & 6 (8.1\%) & $5(4.34 \%)$ & $11(5.82 \%)$ \\
\hline NHL & $12(16.21 \%)$ & $4(3.47 \%)$ & $16(8.46 \%)$ \\
\hline Thyroid & 0 & $4(3.47 \%)$ & $4(2.11 \%)$ \\
\hline $\begin{array}{c}\text { Other } \\
\text { malignancies }\end{array}$ & $14(18.91 \%)$ & $3(2.6 \%)$ & $18(9.52 \%)$ \\
\hline Total number & 74 & 115 & 189 \\
\hline \multicolumn{4}{|c|}{$\begin{array}{l}\text { Table 1. Showing Pattern of Malignancies in Male and } \\
\text { Female Patients in the Study with ' } n \text { ' representing the } \\
\text { Number of Patients and Percentage of Patients (\%) in } \\
\text { Parenthesis. N/A is not applicable, HNNC= Head and Neck } \\
\text { Cancer, NHL= Non-Hodgkin's Lymphoma }\end{array}$} \\
\hline
\end{tabular}

\section{DISCUSSION}

About $93 \%$ of HIV/ AIDS patients live in less developed countries including Africa, Asia including India and Latin America. The incidence of HIV and AIDS in India is high, but the literature on epidemiology of malignancies in HIV from India is sparse. The available literature on Indian patients is from small studies. 5 The incidence of malignancy in HIV patients is higher than general population, as they are more prone for maligancy. ${ }^{1-4}$ The spectrum of malignancies in our study is different from that noted in other studies, which were also single institute studies.

Majority of the Indian patients with ADCs or NADCs were males $^{6}$ in previous studies, but in our study majority $61 \%$ of the patients were females $(115 / 189)$. The ADCs were more common in a previous study ${ }^{7}$ done on South Indian patients. But in our study, the ADCs were seen in $47.6 \%$ (90/189) and NADCs were seen in $52.38 \%$ (99/189) of patients.

No case of Kaposi's sarcoma was reported in our study and in the two previous studied from India. ${ }^{6}$ In a study done on 77 HIV patients in South India, ${ }^{6}$ the most common cancers in male HIV patients were NHL, oral cancers, lung cancer and soft tissue sarcoma, while the spectrum in our study was different. In our study, the most common malignancies in male HIV patients were HNNC followed by NHL, carcinoma penis, rectum and anal cancer.

In previous studies, common cancers in female Indian HIV patients were NHL, breast and cervical cancer. ${ }^{6}$ In our study in female HIV positive patients, the most common malignancy was carcinoma cervix followed by carcinoma breast and other cancers- HNNC, NHL and thyroid.

According to literature available on males proportionate incidence rate (PIR) was increased for anal cancer, Hodgkin's disease, testicular cancer, colon cancer and some HNNC. Among females the PIRs were increased for cervical, vaginal and anal cancer. One study showed increased PIR in male HIV patients for penile carcinoma and for thyroid and pancreas carcinomas and AML in female HIV patients. ${ }^{6}$

Most common malignancy in Indian HIV patients was NHL according to previous studies.5,6 In our study, the most common malignancies in HIV positive patients were carcinoma cervix, HNNC, carcinoma breast, carcinoma penis and anal canal and rectum cancers. Other malignancies like testicular cancer, Hodgkin's lymphoma, vaginal cancer, pancreatic cancer and acute leukaemia were not seen in our study.

The incidence of HNNC is higher among Indian population than west. This is due to the use of oral tobacco and betel nut and areca nut. ${ }^{7}$ Similarly, penile cancers are seen more frequently among Indian population than described in the west. 8,9 The spectrum of cancers among Indian HIV patients include common malignancies or those related to HPV infection like that seen in the west. India is a diverse country with cultural variations among different states of India. The variations in the pattern and spectrum of malignancies in HIV positive Indian patients done at different institutes within India could be due to institutional and geographic variations. Hence, larger multi-institutional studies are needed to further evaluate the epidemiology of malignancies in HIV patients.

\section{CONCLUSION}

The NADCs are more common than ADCs among Indian HIV patients. Females who are HIV positive are more prone for malignancy than males. The common malignancies in Indian female HIV patients are carcinoma cervix and carcinoma breast. The male HIV patients with malignancy commonly have HNNC followed by NHL, carcinoma penis, rectum and anal cancer. Carcinoma penis is high in Indian HIV infected males. The spectrum of malignancies in HIV positive patients in our institute is different from west, but comparable to other institutes in India.

\section{REFERENCES}

[1] Grulich AE, van Leeuwen MT, Falster MO, et al. Incidence of cancers in people with HIV/AIDS compared with immunosuppressed transplant recipients: a meta-analysis. Lancet 2007;370(9581):59-67.

[2] Rubinstein PG, Aboulafia DM, Zloza A. Malignancies in HIV/AIDS: from epidemiology to therapeutic challenges. AIDS 2014;28(4):453-65.

[3] American cancer society. 2014 ACS on HIV, AIDS, cancer. cancer.org. Available from: https://www.cancer.org/cancer/cancercauses/infectious-agents/hiv-infection-aids/hiv-aidsand-cancer.html. 


\section{Jemds.com}

[4] Dhir AA, Sawant S, Dikshit RP, et al. Spectrum of HIV/AIDS related cancers in India. Cancer Causes Control 2008;19(2):147-53.

[5] Sharma SK, Soneja M, Ranjan S. Malignancies in human immunodeficiency virus infected patients in India: initial experience in the HAART era. Indian Journal of Medical Research 2015;142(5):563-7.

[6] Prem S, Narayanan G, Puthuveettil J, et al. Spectrum of HIV/AIDS-associated cancers in south India. J Clin Oncol 2014;32(15):e12534.

\section{Original Research Article}

[7] Joshi P, Dutta S, Chaturvedi P, et al. Head and neck cancers in developing countries. Rambam Maimonides Med J 2014;5(2):e0009.

[8] Dawle AV, Umbrajkar H. Carcinoma of penis: its incidence and management. MedPulse-International Medical Journal 2015;2(3):148-52.

[9] Hakenberg OW, Compérat EM, Minhas S, et al. EAU guidelines on penile cancer: 2014 update. Eur Urol 2015;67(1):142-50. 